\title{
Competition for private capital and central grants: the case of Japanese industrial parks
}

\author{
Shun-ichiro Bessho ${ }^{\dagger} \quad$ Kimiko Terai ${ }^{\ddagger}$
}

This draft: September 29, 2008

\begin{abstract}
We construct a simple model of fiscal competition taking 'rent-seeking' behavior of local governments into account and estimate a policy reaction function based on the model. We consider the scale of public input as each local government's policy tool. Local autonomies' method of seeking central grants often takes the form of personnel exchange with central government. Our estimation of the policy reaction function suggests that such personnel exchange has an effect on the development of industrial parks.
\end{abstract}

Key words: business area development, policy competition, rent-seeking, spatial

\footnotetext{
${ }^{*}$ We would like to thank Toshihiro Ihori, Amihai Glazer, Masayoshi Hayashi, Takaaki Takahashi, Toru Nakazato, Shoichiro Ishibashi, Gerhard Glomm, Kota Sugahara and seminar participants at Aichi University, UC Irvine and Kyushu University for valuable suggestions, and Mitsunari Ishida for his research assistance. We also appreciate kind permission from Yosuke Sunahara for usage of his data on National Diet members. Financial support by the Japan Securities Scholarship Foundation is gratefully acknowledged. The usual disclaimer applies.

${ }^{\dagger}$ School of International and Public Policy and Department of Economics, Hitotsubashi University, 2-1 Naka, Kunitachi, Tokyo, 186-8601 Japan. E-mail: bessho@econ.hit-u.ac.jp

${ }^{\ddagger}$ Professor, Hosei University, and Visiting Researcher, University of California, Irvine. Department of Economics, University of California, Irvine, 3151 Social Science Plaza, Irvine, CA 92697, USA. E-mail: terai@hosei.ac.jp
} 
model

JEL codes: H11, H54, H76, H77, R53 


\section{Introduction}

One way for local governments to develop their region is to bring in new firms. This is one reason why many local governments invest in infrastructure as well as provide financial incentives, such as tax reductions or subsidies. Japanese local governments are not exceptions. One common form of infrastructure in Japan is called an industrial park. Local governments level an area of land, have water pipes and electric lines laid and prepare the ground for new plants and firms. East Tomakomai is a typical example of the development of industrial parks in Japan, some of which seem to be under-occupied, as in Europe (Jayet and Paty 2006). Almost half (4,494 hectares out of 10,700 hectares, based on the Guide of Industrial Estates 2007) of the East Tomakomai area, which has been under development since the early 1970s, was still for sale in 2007. The Guide in 2007 showed more than 15,000 hectares were still for sale in lots nationwide. What is the reason for this over-investment in industrial parks? Because industrial estates are usually developed by local governments, and because their investments in industrial infrastructure could be important incentives for attracting private capital, such overinvestment in industrial estates may be a consequence of fiscal competition among local governments (Taylor 1992, Jayet and Paty 2006) ${ }^{1}$. In addition, since investment in industrial estates needs subsidies from the central government under the current Japanese local finance system, lobbying by local governments for financial support could be going on at the same time.

In order to investigate the determinants of the magnitude of infrastructure investment by local governments put in fiscal competition, we construct a simple model which incorporates 'rent-seeking' behavior of local governments, and estimate a policy reaction

\footnotetext{
${ }^{1}$ For theoretical analyses on the composition of public expenditure as a consequence of interjurisdictional competition, see also Keen and Marchand (1997) and Matsumoto (2000, 2004).
} 
function based on the model. Our model captures two salient features of the Japanese local public finance system. First, the differences in Japanese local tax rates are small since the allowable range of local tax rates is set by national law, and hence it seems implausible to treat a tax rate as a choice variable of local governments. In our model, they compete with each other by choice of the level of public input. Second, frequent personnel exchanges between the central and local governments can be considered an effective way for local governments to highlight their desire for fiscal aid from the central government, for the development of industrial parks. By employing a spatial lag model which is consistent with our theoretical model analysis, we estimate the policy reaction function of Japanese prefectures using the industrial parks data, as well as the data on personnel exchanges. We believe that the stock of public input or infrastructure directly matters, rather than local government expenditures, in attracting private capital. Our estimate results suggest that a local Japanese government's choice of the size of industrial parks responds to the neighboring government's policy choice and that the number of prefectural government employees working in the central ministries has more definitely positive effects on the size of industrial parks. Thus, we have found evidence of inter-regional competition in Japan in two dimensions: in inviting private capital and in seeking central subsidies.

Our theoretical consideration of local governments' strategic interaction is based on a quite simple model. This model composition substantially relies on wisdom accumulated during previous works on fiscal competition. Many of them examine local governments' strategic choices of a tax rate on mobile factors (e.g., Zodrow and Mieszkowski 1986, Wildasin 1988, Bucovetsky 2005). Other works focus on central government's role in correcting externalities arising from local governments' tax competition (e.g., Dahlby 1996, Bucovetsky, Marchand, and Pestieau 1998, Köthenbürger 2004, Köthenbürger 2007, 
Breuillé, Madiès, and Taugourdeau 2008). In addition, it should be noted that our underlying idea has been inspired by some signaling models in which lobbying is treated as the strategic transmission of information by special interests (e.g., Austen-Smith and Wright 1992, Potters and van Winden 1992, Esteban and Ray 2000, 2006). ${ }^{2}$

There has been a surge of empirical research on strategic interaction among local governments, as surveyed in Brueckner (2003), Revelli (2006) and Anselin (2007). While common strategic instruments are tax rates, interaction in the setting of expenditure is also examined (Case et al. 1993, Baicker 2005, Revelli 2006, Moscone et al. 2007, Costa-font and Pons-novell 2007). One of our contributions in the empirical analysis is the use of data on industrial park areas and values, rather than expenditures. It is true that expenditure is one of the indices of local governments' efforts to attract private capital, but we believe that private capital would respond to goods or services that local governments provide, rather than their expenditures.

We assume in this paper that Japanese local governments compete with each other with respect to how large or how valuable the industrial parks are that they offer. Another contribution in our empirics is to utilize the data on personnel exchange between local and central governments to proxy the degree of 'rent-seeking'. Recently, the effects of political factors on public good provision have been empirically investigated (e.g., Calabrese et al. 2006, Costa-font and Pons-novell 2007). In particular, Doi and Ashiya (1997) showed how national incumbents affect the choice of local public works in Japan. These empirical works use data on elections or the traits of elected representatives, whereas our work focuses on government bureaucrats' behavior at the administrative stage. Observing the close connection and daily interaction between local and central government officials in Japan, we can infer that a stronger link between the two should benefit both or either of

\footnotetext{
${ }^{2}$ For the survey of political economy of fiscal federalism, see Sato (2007)
} 
them. The volume of personnel exchange is one measure of the link, and we find positive effects of this personnel exchange on industrial park development.

The rest of this paper proceeds as follows. Section 2 explains institutional features of the Japanese local public finance system. Section 3 presents theoretical considerations, and based on this model we show our empirical analysis in Section 4. Section 5 concludes.

\section{Institutional Background}

If we look down from the top of hierarchy ${ }^{3}$, it can be seen that the Japanese public sector comprises three tiers of government: a central government, 47 prefectures, and about 1800 municipalities. Prefectures and municipalities are taken as local autonomies, and any municipality is spatially contained within the boundary of a certain prefecture. Japan is usually categorized as a unitary state. Japanese laws have endowed the central government with regulatory power over local autonomies. For instance, the central government sets the standard and upper-limits of local tax rates for many tax instruments; also, advance consultation with the Minister of Home Affairs is required for issuing local bonds. Following the enactment of the Comprehensive Decentralization Law in 1999, central regulation of local finance has been gradually loosened, but it is difficult to say that each local government is given a free hand in deciding its own fiscal policies.

A large proportion of public work projects in Japan are actually implemented on the initiative of local autonomies. Public investment in industrial parks, which are developed and maintained to attract manufacturing plants, is also usually administered by local governments. Facilities completed through public works are usually used for several decades, so that they should be deliberately planned. In Japan, public works are executed

\footnotetext{
${ }^{3}$ See Reed (1986) for political scientific analysis of Japanese prefectures.
} 
according to administrative plans, which in fact need to be approved by central line ministries.

A feature of the Japanese local finance system is a large vertical fiscal imbalance. Local expenditures are about twice those of the central government, while the reverse is true for revenues. Japanese local governments are highly dependent on fiscal transfers from the central government, which subsidize many public works projects. The main subsidies from central government to local governments are categorized into two types: central government subsidies and local allocation tax grants. The former are purpose-specific, or in many cases matching, grants while the latter are general purpose grants. Under such a fiscal system it is rational for local autonomies to lobby for central government aid, as the members of the Prime Minister's consultative organ Council on Economic and Fiscal Policy admitted in its report of May 18, 2001. Competition among local autonomies petitioning for central approval on and subsidy for a public work at its early stage has been evident since the early 1960s, when the National Comprehensive Development Plan (so-called 'Zenso' in Japanese) was put into action to promote industrialization and balanced economic growth in Japan.

There have been empirical studies by economists and political scientists examining the influence of political factors on the implementation of public works in Japan (e.g., Abe, et al. 1990, Doi and Ashiya 1997). In particular, some have focused on the coordination and agreement between central and local governments at the stage of setting out an administrative plan. For instance, Nishio (1990) says that this coordination benefits the central government, which is at the top of the hierarchy, since it can establish a cooperative relationship with subordinate agents from the very early stage of a project. It has also been shown that frequent and institutional contacts between personnel of central government and those of prefecture government have enabled such close coordination 
(Nishio, 1990, pp. 223-224). Interchange of personnel between the local and the central governments is one institutional method of contact (Reed 1986). Various forms of personnel interchange are observed: some prefectures invite a central bureaucrat to act as a vice-governor or a director of a department; in their place, some prefecture officers are sent to central government on loan. Shimokobe (1994) points out that local government can effectively communicate with central government by placing the central officer as a prefecture director. This suggests that interchange of the personnel works in a practical way to foster inter-governmental communication or transmission of information. Thus, each local government can employ certain routes to work on central government, which induce it to act strategically against its rivals' behavior.

\section{Theoretical Predictions}

We start by deducing theoretical implications from a simple model in which each local government's public expenditure is used on public input to enhance the production of a private good. The model does not involve local choices of tax rate on mobile factors, a problem which has been intensively studied in the literature on fiscal competition. In Japan, the range of allowable local tax rates is specified by national law. For instance, prefectural governments in Japan can impose a prefectural inhabitant tax and a business tax upon businesses. For the prefectural inhabitant tax on business income, the national law sets the standard tax rate and the upper limit of the allowable tax rate as $5 \%$ and $6 \%$, respectively; for the prefectural business tax, the standard tax rate is specified for each of the business's value added, capital, and income, and the upper limit of its allowable tax rates is each standard tax rate times 1.2. It is therefore difficult to say that each local government is given a free hand in selecting tax rates. Rather, it seems natural to regard 
the scale of public investment as the primary variable of Japanese local governments.

Jurisdictions. The economy consists of small jurisdictions. Each of them is inhabited by a single household. Let the household in a jurisdiction $i$ own the fixed level of private capital $\bar{K}_{i}$. Capital is perfectly mobile across jurisdictions so that all capital earns the same return.

Production. Output is produced in each jurisdiction by perfectly competitive businesses. Their technology is aggregated by a continuously twice differentiable production function $F_{i}$ which is strictly increasing and strictly concave in each input:

$$
Y_{i}=F_{i}\left(K_{i}, \Gamma_{i}\right)
$$

where $Y_{i}$ denotes the output of a numeraire private good in jurisdiction $i ; K_{i}$ is private capital employed there; $\Gamma_{i}$ denotes the scale of public capital available to businesses in the district. We suppress some locationally-fixed inputs, such as land and labor, which are owned by local residents. Let expression $F_{i}$. $\left(F_{i . .}\right)$ represent the first (second) partial derivative of $F_{i}$ with respect to the subscript(s). Similar expressions apply to the other functions. The assumption of $F_{i K_{i} \Gamma_{i}}>0$ appears to be plausible. It implies that public capital works raise the marginal productivity of private capital.

Private capital is employed by each business up to the extent where the first-order condition for profit maximization holds. In the aggregate, it is given by

$$
F_{i K_{i}}\left(K_{i}, \Gamma_{i}\right)-r=0,
$$

where $r$ is the nationwide return to private capital. Condition (2) suggests that local capital demand depends on $\Gamma_{i}$ and $r$. ¿From (2) and the assumptions of $F_{i K_{i}}>0$ and 
$F_{i K_{i} K_{i}}<0, \frac{\partial K_{i}}{\partial r}<0$ is straightforwardly shown.

We suppose that $r$ is determined where the total private capital demand meets its total supply, i.e., where the following condition for the domestic capital market equilibrium holds:

$$
\sum_{i} K_{i}=\sum_{i} \bar{K}_{i}
$$

according to the traditional fiscal competition model. Even if we supposed that the return to private capital is determined exogenously in the international capital market, implications from the analysis of the model would not be changed.

The system comprising condition (2) for all $i$ and condition (3) thus gives us each local demand for private capital as well as the equilibrium return on it as functions of public capital allocation:

$$
\begin{aligned}
K_{i} & =K_{i}\left(\Gamma_{i}, \Gamma_{-i}\right), \forall i ; \\
r & =r(\Gamma),
\end{aligned}
$$

where $-i$ represents jurisdictions other than $i$ and $\Gamma_{-i}$ denotes the vector of their public capital levels; $\Gamma$ denotes the entire vector of public capital levels in all jurisdictions. These expressions will apply for other variables. Note that (4) is common knowledge to each government at any level. It follows from (2) and the assumptions of $F_{i K_{i} \Gamma_{i}}>0$ and $F_{i K_{i} K_{i}}<0$ that

$$
\frac{\partial K_{i}}{\partial \Gamma_{i}}>0, \frac{\partial K_{j}}{\partial \Gamma_{i}}<0, \frac{\partial r}{\partial \Gamma_{i}}>0 .
$$

The derivation of (5) is given in detail in the Appendix. An increase in public capital 
in one district leads to an increase in the demand for private capital there, thereby raising the return on it in equilibrium and absorbing the neighbors' capital. It is a fiscal externality that each local government does not count. We cannot determine the sign of the second derivatives without further specification of model composition.

Vertical Fiscal System of the Public Sector. The purpose of this work is to investigate how local governments compete with each other in public capital provision. It is often said, however, that the interjurisdictional competition in Japan in this category appears to be greatly controlled, subject to the grant scheme implemented by the central government. Indeed, it is an important role of the central government to redistribute funds and to control inter-jurisdictional disparity in public goods. Knowing this, each jurisdiction may seek to gain more funds from the center. This can lead to another type of competition among districts, which we will hereinafter refer to as a "rent-seeking competition". The term "rent" refers to public funds given to a district at the discretion of the central government. The well-known rent-seeking behavior of Japanese local governments is to frequently visit central officials to explain their need for central aid. This action is often called a chinjo (a petition for aid). But the more hidden way of communicating their need is to utilize the system of a jinji-koryu (an interchange of personnel between the local and central governments). It is attractive for us to focus on the latter since the data on the number of officials interchanged are available from open sources, and they are highly accurate and credible. We compose a model to be used for empirical investigation, which incorporates local governments' rent-seeking competition and their direct competition for inviting private capital investment. It enables us to examine which competition is more significant for Japanese local governments.

Let $T_{i}$ denote the lump-sum tax collected by local government $i$. It is decided accord- 
ing to

$$
\begin{aligned}
\Gamma_{i} & =(1-\delta) \Gamma_{i,-1}+G_{i}, \\
T_{i} & =G_{i}-Z_{i},
\end{aligned}
$$

where $\delta$ denotes depreciation rate of capital; $\Gamma_{i,-1}$ is the level of public capital in jurisdiction $i$ in the previous period; $G_{i}$ represents jurisdiction $i$ 's public investment; $Z_{i}$ denotes the grant from the central government to $i$. Note that $G_{i}, T_{i}$, and $Z_{i}$ are measured in real terms.

Let $e_{i}$ denote local government $i$ 's level of effort at rent-seeking. In our context, it relates to the number of local and central officers who are interchanged, although we suppose $e_{i}$ to be continuous for the convenience of theoretical analysis. Transferral to the center of local government employees who have specific skills and useful information about their local area, in place of having new persons from the center, generates cost to the local government. Thus, every local government $i$ 's payoff can be formulated as

$$
V_{i}=V\left(Y_{i}, T_{i}, e_{i}\right)
$$

Suppose that the function $V$ is continuously differentiable in each argument, strictly increasing in $Y_{i}$, and strictly decreasing in each of $T_{i}$ and $e_{i}$. With higher $Y_{i}$, the resident might gain a higher income from holding locally-fixed factors. This would lead to higher evaluation of the local government's policy. On the other hand, higher $T_{i}$ bears hard on the resident's budget, while higher $e_{i}$ might constrain the manpower of the local government, forcing it to lower the quality of other public goods for the resident. 
Let the payoff function of the central government be

$$
\sum_{i} V_{i}+W(e)
$$

where $W$ is continuously differentiable and strictly increasing in each $e_{i}$. Thus, an exchange of information with local governments via the personnel interchange system assists the central government's effective policy choice process and its governance of the nation. Equation (8) also implies that the central government is partially benevolent in that it values local welfare. The central government faces the balanced-budget constraint

$$
\sum_{i} Z_{i}=\bar{R}
$$

where $\bar{R}$ denotes the fixed amount of common funds to be distributed among districts.

We construct a multi-stage game to describe local and central governments' behavior. The timing is:

1. The central government designs the rule for setting the grant $Z_{i}$ as a continuously differentiable function of any local government $i$ 's public investment and its effort level for rent-seeking, i.e., $Z_{i}=Z\left(G_{i}, e_{i}\right)$;

2. Each local government $i$ simultaneously and independently chooses $e_{i}$;

3. Each local government $i$ simultaneously and independently chooses $G_{i}$,

and then $T_{i}$ is collected according to $(6) .{ }^{4}$ Note that the rule represented by function $Z$ is commonly applied to every $i$. The promise made at the first stage in the form of the function of the future action can be considered as being binding because if the central

\footnotetext{
${ }^{4}$ Our assumption of sequential choices of $e_{i}$ and $G_{i}$ is to make the timing in the theoretical model consistent with the estimation procedure. The simultaneous choices do not change the theoretical results.
} 
government reneges on its promise this is likely to trigger local government disobedience. We summarize a pure strategy of each local government $i$ as $s_{i}=\left(G_{i}, e_{i}\right)$, while a strategy of the central government is a choice of $Z(\cdot, \cdot)$. The equilibrium concept we use to solve the game is Subgame Perfect Nash.

Equilibrium. To determine an equilibrium, we construct strategies by solving the game backwards. From (1), (4), (6), and (7), at the third stage of the game, with $Z(\cdot, \cdot)$ being given and $e_{i}$ having been decided, each local government $i$ chooses $G_{i}$ which maximizes

$$
\tilde{V}\left(G_{i}, G_{-i}, e_{i}\right) \equiv V\left(F_{i}\left(K_{i}\left(\Gamma_{i}, \Gamma_{-i}\right), \Gamma_{i}\right), G_{i}-Z\left(G_{i}, e_{i}\right), e_{i}\right),
$$

regarding $G_{-i}$ as given and anticipating (5). Note that (10) uses the fact that given $\Gamma_{i,-1}$, choosing $G_{i}$ is equivalent to choosing $\Gamma_{i}$ in each jurisdiction $i$. Suppose that we can derive the unique internal solution of $G_{i}$ from the first-order condition. ${ }^{5}$ It is given by

$$
\tilde{V}_{G_{i}}\left(G_{i}, G_{-i}, e_{i}\right)=V_{Y_{i}}\left(F_{i \Gamma_{i}}+F_{i K_{i}} \frac{\partial K_{i}}{\partial \Gamma_{i}}\right)+V_{T_{i}}\left(1-Z_{G_{i}}\right)=0 .
$$

The respective terms in the first pair of parentheses on the right-hand side of the first equality in (11) correspond to the direct effect of jurisdiction $i$ 's public investment on production, and its indirect effect on production through attracting private capital from the neighboring districts. The second term on the right-hand side of the first equality in (11) represents the change in $V_{i}$ caused by increased tax imposition. Thus, (11) equates the marginal benefit of $i$ 's policy choice with its marginal cost.

\footnotetext{
${ }^{5}$ This supposition has been employed in solving governments' maximization problems in the literature on estimating interregional reaction function, since it is difficult to prove the satisfaction of second-order conditions and the uniqueness of the solution without further specification.
} 
Equation (11) gives us i's reaction at this stage against the other jurisdictions' choices:

$$
G_{i}=R\left(G_{-i} \mid e_{i}\right)
$$

Investigating (12) empirically is the purpose of this work. Recall from (5) that given $G_{-i}$, an increase in $G_{i}$ deprives jurisdiction $j, j \neq i$, of private capital. If $\frac{\partial G_{i}}{\partial G_{j}}>0$, jurisdiction $i$ becomes more aggressive in the face of more aggressive policy choice by jurisdiction $j$. If $\frac{\partial G_{i}}{\partial G_{j}}<0$, jurisdiction $i$ becomes more accommodative to more aggressive policy choice by its rival. By using the implicit function theorem, we can derive $\frac{\partial G_{i}}{\partial G_{j}}=-\frac{\tilde{V}_{G_{i} G_{j}}}{\tilde{V}_{G_{i} G_{i}}}$ from (11), but its sign is unpredictable theoretically without further specification of the model.

At the second stage, anticipating (5) and (11), the local government $i$ maximizes (10) by choosing the optimal level of $e_{i}$. As in computation at the third stage, suppose that local government $i$ 's optimal choice of $e_{i}$ is derived as a unique internal solution from the first-order condition. By relying on the envelope theorem, we derive the first-order condition with respect to $e_{i}$ as

$$
\tilde{V}_{e_{i}}\left(G_{i}, G_{-i}, e_{i}\right)=-V_{T_{i}} Z_{e_{i}}+V_{e_{i}}=0
$$

which can be rearranged as

$$
Z_{e_{i}}=\frac{V_{e_{i}}}{V_{T_{i}}}
$$

Equation (13) implies that, in equilibrium, $i$ 's marginal rate of substitution between rentseeking effort and grant acquisition should equal the marginal payment by the central government for its effort. Thus, given a grant scheme, each local government $i$ can successfully inform the central government of its need for grants.

The central government's task at the first stage is to decide which way to distribute 
the fixed amount of funds, anticipating (5), (11), and (13). Note that with the grant scheme $Z(\cdot, \cdot)$ settled by the central government, $s_{i}=\left(G_{i}, e_{i}\right)$ to be selected subsequently by the local governments should maximize the central government's payoff (8) subject to (9), otherwise the central government could have deviated and increased its own payoff. By utilizing (11) and (13), we can derive the associated first-order conditions with regard to $G_{i}$ and $e_{i}$ as

$$
\begin{aligned}
& \sum_{j \neq i} V_{Y_{j}} F_{j K_{j}} \frac{\partial K_{j}}{\partial \Gamma_{i}}-\lambda Z_{G_{i}}=0, \\
& W_{e_{i}}-\lambda Z_{e_{i}}=0
\end{aligned}
$$

where $\lambda(>0)$ is a Lagrange multiplier on the budget constraint (9) and therefore captures the severity of local governments' competition to extract rent from a common pool of central funds. Equations (14) and (15) suggest that anticipating local governments' subsequent choices, central government sets $Z(\cdot, \cdot)$ to satisfy $Z_{G_{i}}<0$ and $Z_{e_{i}}>0$ on the equilibrium path. These conditions come from (5) and our assumptions on the monotonicity of the functions $F_{i}, V$, and $W$. They imply that the grant should rise around each local government's equilibrium rent-seeking effort, since it is paid in compensation for delivering beneficial information for central governance; it should fall around the equilibrium public investment level since the Benthamite central government attempts to design a grant scheme which can solve the externality problem produced by each local government's aggressive policy choice.

Let a superscript $*$ represent an equilibrium. Then, from (9), (11), (13), (14), and 
(15), we obtain

$$
\begin{aligned}
Z_{G_{i}}^{*}\left(G_{i}^{*}, e_{i}^{*}\right) & =\frac{\sum_{j \neq i} V_{Y_{j}} F_{j K_{j}} \frac{\partial K_{j}}{\partial \Gamma_{i}}}{\lambda^{*}}\left(G_{i}^{*}, G_{-i}^{*}, e_{-i}^{*}\right) \\
& =\frac{V_{Y_{i}}\left(F_{i \Gamma_{i}}+F_{i K_{i}} \frac{\partial K_{i}}{\partial \Gamma_{i}}\right)+V_{T_{i}}}{V_{T_{i}}}\left(G_{i}^{*}, G_{-i}^{*}, e_{i}^{*}\right)<0, \forall i \\
Z_{e_{i}}^{*}\left(G_{i}^{*}, e_{i}^{*}\right) & =\frac{W_{e_{i}}}{\lambda^{*}}\left(e_{i}^{*}, e_{-i}^{*}\right)=\frac{V_{e_{i}}}{V_{T_{i}}}\left(G_{i}^{*}, G_{-i}^{*}, e_{i}^{*}\right)>0, \forall i, \\
\sum_{i} Z^{*}\left(G_{i}^{*}, e_{i}^{*}\right) & =\bar{R} .
\end{aligned}
$$

Conditions (16) to (18) give us $s_{i}^{*}=\left(G_{i}^{*}, e_{i}^{*}\right)$ to be supported by $Z^{*}(\cdot, \cdot)$ and the property of $Z^{*}(\cdot, \cdot)$ is in the close neighborhood of $s_{i}^{*}=\left(G_{i}^{*}, e_{i}^{*}\right)$, for all $i$, as well as $\lambda^{*}{ }^{6}$ Equations in (16) show, as we mentioned above, that in equilibrium the central government designs the grant scheme which can internalize externalities produced by inter-regional competition and, given the scheme, each local government chooses the optimal level of public investment. Also, (17) shows that in equilibrium each local government's marginal rate of substitution between rent-seeking effort and grant receipt coincides with the central government's marginal evaluation of its effort. Condition (18) requires that the transfer scheme is feasible in equilibrium.

\footnotetext{
${ }^{6}$ We cannot uniquely determine the property of $Z^{*}\left(G_{i}, e_{i}\right)$ for $\left(G_{i}, e_{i}\right)$ off the equilibrium path. This is a familiar argument which arises in the analysis with a pre-scheduled compensation scheme. For instance, among previous works employing a multiprincipal setting, Bernheim and Whinston (1986), Grossman and Helpman (1994), and Dixit, Grossman, and Helpman (1997) put restrictions on compensation for off-the-equilibrium strategies and coped with the problem of multiplicity of equilibria. The purpose of our theoretical analysis is to deduce the equilibrium condition to test, relying on the idea that observances can be treated as equilibrium outcomes. Therefore indeterminateness of the grant schedule off the equilibrium does not hinder our subsequent analysis.
} 
Jurisdiction $i$ 's reaction function in (12) now satisfies

$$
G_{i}^{*}=R\left(G_{-i}^{*} \mid e_{i}^{*}\right)
$$

Our focus is on testing whether our presupposition of two-dimensional competitions is supported by the data. We take observances as equilibrium outcomes and estimate the linear approximation of (19) with them. If the estimated slope of $G_{-i}$ is significant, we can say that local governments compete for inviting private capital. If the estimated coefficient of $e_{i}$ is also significant, rent-seeking competition is evident.

\section{Empirical Analysis}

\subsection{Estimation strategy}

Since our focus of interest is the assessment of the existence and the strength of interaction among local governments, we employ here a spatial lag model consistent with our theoretical analysis above (e.g., Anselin 2001) ${ }^{7}$. Our base estimation equation is:

$$
G_{i}=\phi w_{i} G_{-i}+\psi e_{i}+\mathbf{X}_{i} \beta+\varepsilon_{i},
$$

where $G_{i}$ is industrial park development by each prefectural government. $w_{i}$ is an exogenous weighting vector of "neighborliness", where the sum of elements is normalized to unity, and $G_{-i}$ is a vector representing industrial estate development in "neighboring" prefectures. $e_{i}$ represents a rent-seeking behavior of local governments, measured by personnel exchange. $\mathbf{X}_{i}$ is another explanatory variables vector with the corresponding

\footnotetext{
${ }^{7} \mathrm{As}$ is discussed in Brueckner (2003) and Rebelli (2005), our specification cannot discriminate our fiscal competition hypothesis from other possible theories, such as technological spill-over or yardstick competition theories.
} 
coefficient vector $\beta . \varepsilon_{i}$ is an error term that is possibly correlated with each other, as discussed later.

As is stressed in the spatial econometric literature, the explanatory variable $w_{i} G_{-i}$ is endogenous because we assume the strategic interaction between local governments, and the OLS estimator is typically inconsistent. One way to deal with this endogeneity problem is to instrument this explanatory variable, $w_{i} G_{-i}$. The instruments have to be correlated with $w_{i} G_{-i}$ (relevancy) and uncorrelated with the error term, $\varepsilon_{i}$ (exogeneity). We here assume the other explanatory variables are exogenous, and then $w_{i} \mathbf{X}_{i}$ and $\left(w_{i} w_{i}^{\prime}\right) \mathbf{X}_{i}$ are valid instruments (e.g., Revelli 2006) ${ }^{8}$.

If there are other sources of spatial interdependence than that captured through $w_{i} G_{-i}$, the error term, $\varepsilon_{i}$, can be spatially correlated with each other $\left(E\left[\varepsilon_{i} \varepsilon_{j}\right] \neq 0\right)$. This correlation is often assumed to be spatially autoregressive. Although maximum likelihood procedures have been suggested in the literature, Kelejian and Prucha (1998) propose a computationally simpler procedure. The Kelejian-Prucha two-stage method requires us to choose a spatial weighting matrix for the spatial-lag and spatial-error term. Fortunately, the autoregressive parameters for the spatial-error term estimated using the Kelejian-Prucha method are not statistically different from zero, thus we report the results without spatially autoregressive disturbances in what follows.

\subsection{Data and variables}

Our dependent variable $G_{i}$ represents the area or the value of newly developed industrial parks in each prefecture. Our data on the area of industrial parks are obtained from "Nihon Ritchi Soran" (Comprehensive List on Industrial Locations in Japan) from 2001

\footnotetext{
${ }^{8}$ Baicker (2005) utilizes other instruments excluded from $\mathbf{X}_{i}$ "that are less likely to be correlated with omitted state characteristics (Baicker 2005, p.535)".
} 
to 2007, which contains information on the location, the gross area and the names of firms (scheduled to be) located in each industrial estate. The List is about industrial parks that are for sale or under construction, and it excludes those where the setups of the industrial plants are completed. We construct the area data on industrial parks in each prefecture that are newly developed between 2003 and 2007. We pick up such industrial parks that appear in the List between 2003 and 2007 and that are not found in 2001 and 2002, so as to sum up the areas for each prefecture, as shown in Figure 1. The total number of the selected areas is 203 (4.32 areas per prefecture), the total area is 148.2 million square meters (the prefectural average is 3.15 million square meters). Four prefectures (Yamanashi, Nara, Nagasaki and Oita) have not developed any industrial parks during this period.

We also pick up data on the average land price of industrial parks in 2001 in each prefecture from "Kojo Tekichi Soran" (Comprehensive List on Suitable Sites for Factories). The expected values of newly developed industrial parks are obtained by multiplying this price and the area. The prices are assumed to be exogenous for prefectural governments. We assume here that these values reflect those of industrial parks prefectures provide to private sectors.

The effort level of "rent-seeking" of local governments is measured by personnel exchange. The data on personnel exchange can be obtained from Nikkei Glocal. Since this monthly magazine gives detailed information once a year from 1996, we utilized the information on the directors of commerce and industry of the prefectures and the number of prefectural government employees who worked in the central government in $2000^{9}$.

Other explanatory variables include the number of members of the Liberal Demo-

\footnotetext{
${ }^{9}$ Nine prefectures have directors transferred on loan, 5 from the Ministry of International Trade and Industry, 2 from the Ministry of Home Affairs, and 2 from the Ministry of Labor.
} 
graphic Party (the governing party in Japan, hereafter LDP) in House of Representatives, population density, local tax revenues, local bonds outstanding and the site area of existing business establishments with more than 30 workers. ${ }^{10}$ All but population density are converted to a per capita basis.

Note that we do not use the variables on subsidies as explanatory variables. As discussed in the "Background" section, the volume of subsidies from the central government to the local governments is determined at the same time. Thus we believe that it is not appropriate to assume that the local governments just respond to the subsidy policies of the central government. In addition, we do not have the proper data to represent the subsidy policies for development of industrial parks.

We explore four different sets of weighting vectors for "neighborliness". The first is based on usual contiguity ${ }^{11}$. The others are defined using tax revenue, gross regional expenditure (GRE) and employees' income per capita. As explained in Section 2, Japanese municipalities are spatially included within a prefecture, thus we use the sum of tax revenues of the prefecture and municipalities contained therein. These three weights reflect the "neighborliness" from a fiscal or economic viewpoint. The weights for the last three measures are calculated based on a "triangular" formula ${ }^{12}$.

The sample statistics are shown in Table 1.

\footnotetext{
${ }^{10}$ Japan currently uses a single-seat constituency/proportional representation system to elect members of the House of Representatives. We included members who were elected in the single-seat constituencies and excluded those elected under proportional representation. The constituency of single-seat formula coincides with or is included within a prefecture while the constituencies of proportional representation cover several prefectures.

${ }^{11}$ We also make use of the distance between the capital cities of prefectures, and the results are quite similar to the contiguity case.

${ }^{12}$ Let us denote the weight attached to a prefecture $j$ for an observation of a prefecture $i$ as $w_{i j}$, the indexes used for calculation of the weights (here, tax revenue per capita, GRE per capita and employees' income per capita) as $x_{i}$, and the sample standard deviation of $x_{i}$ as $\sigma_{x}$. We first calculate $\tilde{w}_{i j}=$ $1-\left|x_{j}-x_{i}\right| /\left(\sigma_{x} / 2\right)$. Then, we define $w_{i j}$ as standardized $\tilde{w}_{i j}$ such that $w_{i j}$ is set to zero if $\tilde{w}_{i j}$ is negative and that $\sum_{j} w_{i j}=1$.
} 


\subsection{Estimation Results}

The estimation results are shown in Tables 2, 3 and 4 .

Tables 2, 3 and 4 show the results based on the simple linear efficient GMM method, where conditional heteroskedasticities are allowed (Hayashi 2000). The dependent variable in Table 2 is the area of the industrial parks, while in Tables 3 and 4 the value is used. Our excluded instruments are spatially weighted exogenous variables, $w_{i} \mathbf{X}_{i}$ and $\left(w_{i} w_{i}^{\prime}\right) \mathbf{X}_{i}$, and the first stage $\mathrm{F}$ statistics show that they are relevant, although the $\mathrm{F}$ statistics are slightly low when the spatial weighting vector is based on contiguity. We also cannot reject the null hypothesis that the instrument variables are exogenous in most cases, based on the over-identification test (Hansen's J statistics). Thus we believe that our instruments are valid.

We assume interior solutions in the theoretical analysis. Thus we show in Table 4 the results when the four prefectures which have not developed any industrial parks during our sample period are excluded ${ }^{13}$. The results in Table 4 are quite similar to those in Table 3, thus we proceed based on the results in Tables 2 and 3.

In Table 2, the coefficients of industrial parks in the "neighboring" prefectures are not so large and statistically insignificant. When the dependent variable is the value of the industrial parks and when "neighborliness" is defined by tax revenue and gross regional expenditure per capita, the coefficients are not very small and statistically significantly positive, as in Table 3 . These positive coefficients could indicate a strategic complementarity of infrastructure investment between neighboring prefectures. In addition, our results imply that the Japanese prefectural governments regard as "neighbors" those which are akin to each other in terms of tax revenues, but not those which are close

\footnotetext{
${ }^{13}$ The data on the four prefectures are utilized in making the weighting matrix, but they are dropped in the estimation.
} 
from the viewpoint of geography. If the prefectural governments were afraid that firms or jobs in their own area might move to geographically neighboring prefectures because the moving or commuting costs may be rather small, the coefficient of industrial parks in the geographically neighboring prefectures should also be estimated to be positive. Thus we can interpret our results as providing support to the fiscal competition hypothesis, in which the prefectural governments are competing with their counterparts that have economically or fiscally similar characteristics. However, we have to admit the possibility that our results stem from yardstick competition or common shocks to the prefectures. These results seem to also be consistent with those of Sugahara and Kunisaki (2006), who investigated the existence and magnitude of fiscal competition among Japanese prefectures using the data on expenditures for commerce, industry and civil engineering to find positive responses to the neighboring local governments.

For most cases in Tables 2 and 3, the coefficients of the number of prefectural government employees who work in the central government are positive, and statistically significant. These results are consistent with our hypothesis that personnel exchange is one way of rent-seeking, as discussed in Section 3. The prefectural government employees working in the central government might be encouraging central government officials to promote regional development in their original prefectures. On the other hand, the coefficients of the directors transferred on loan from the central government are not statistically significantly different from zero. This may reflect the fiscal situation during our sample period, and the directors from the central government have placed emphasis more on fiscal reconstruction than those promoted by the local governments. Our results are in line with those of Sunahara (2006), who examined the relationship between the prefectural expenditures on infrastructure and the backgrounds of the governors and found that the ministry-bureaucrat-turned-governors hold down infrastructure expenditures. 
The coefficients of the number of LDP members in the House of Representatives are estimated to be negative both in Tables 2 and 3. It is a widely accepted view in previous literature, especially in the field of public choice, that the Diet members belonging to the government party have certain powers to afford "pork barrels" to their constituency. In fact, Japanese empirical works (e.g., Doi and Ashiya 1997) have found evidence of this. Our results in Tables 2 and 3 are inconsistent with this view. They seem to be suggesting that building industrial parks is not an attractive political instrument any more for Diet members to collect political support from their constituency. To seek the reason for these results is beyond the scope and the purpose of our analysis, but the following two points are candidates for justifications of our results. First, Japan experienced the reform of its electoral system just before our sample period. The transition from a medium constituency system to a single-seat constituency system in the House of Representatives election might have influenced LDP members to pander to different interest groups, not connected with direct benefits from development of industrial parks. Second, fiscal reconstruction had been emphasized during our sample period under the administration of the Koizumi cabinet. National spending on public works was actually suppressed by the strong initiative of Prime Minister Koizumi. Under the parliamentary system in Japan, he was the leader of the LDP at the same time. His will and leadership might have disciplined the behavior of the LDP members.

Turning now to other explanatory variables, the tax revenues per capita show a negative effect on the development of industrial parks, partly because poor prefectures are more eager to attract new enterprises. The level of bonds outstanding has negative effects. This may reflect the situation where the prefectural governments with huge bonds outstanding have to pay back their debts before constructing new industrial parks. The site area of existing business establishments has positive effects. The prefectures with 
more business establishments might be trying to take advantage of returns to scale, or economies of concentration.

\section{Concluding remarks}

We have investigated the determinants of the scale of public investment in industrial parks in Japan, considering explicitly fiscal competition among local governments. First, we construct a simple model in which each local government's public expenditure is used on public input to enhance the production of a private good. Our model captures two salient features of the Japanese local public finance system: the first is that the differences between Japanese local tax rates are small, since the allowable range of local tax rates is set by national law, and the second is that frequent personnel exchange between the central and local governments is observed. We interpret this personnel exchange as a rent-seeking behavior of local governments by which each of them can communicate its need for fiscal aid from the central government. Second, we estimate the policy reaction function of Japanese prefectures using the industrial parks data as well as the data of personnel exchange. We believe that the scale or value of the public input on infrastructure directly matters, rather than local government expenditures, in attracting private capital. Our estimation results suggest that the Japanese local government's public input policy responds to that of its neighbors, defined from a fiscal or economic viewpoint. Furthermore, it is shown that the number of prefectural government employees working in the central ministries has more definitely positive effects on the size of industrial parks. Thus, inter-regional competition in seeking central aid is more evident than that for inviting private capital in Japan. To determine which competition generates greater inefficiency is beyond the scope of our analysis, but the evidence we found suggests that vertical 
interdependence in the hierarchical fiscal system affects interregional competition.

This paper focuses on the public investment of Japanese local governments in industrial parks. Our analysis of course has some limitations. First, we implicitly assume prefectural governments are decision makers, but there are municipal governments under each prefecture. The former is in the middle and the latter is at the bottom of the hierarchy of the Japanese public sector. Municipal governments, which are smaller-sized and closer to residents than prefectural governments, may respond more evidently to neighbors. Second, as pointed out in Revelli (2005), our estimation strategy cannot identify the fiscal competition effect from technological externalities, common shocks or yardstick competitions. Third, development of industrial parks is not the only way to attract private capital. Fourth, other factors may have more of an effect on the development of industrial parks, which may include the type of prefectural governors. The prefectural governors in Japan have strong authorities. In addition, local governments are also competing in other aspects, such as health or environmental policies. All these are topics for our future research.

\section{A Appendix}

\section{A.1 Derivation of (5)}

The first-order condition (2) should hold for any level of $\Gamma_{i}$ whenever the profit of the production sector is maximized. Therefore, by differentiating (2) with respect to $\Gamma_{i}$, we should have

$$
\frac{\partial K_{i}}{\partial \Gamma_{i}}=\frac{\frac{\partial r}{\partial \Gamma_{i}}-F_{i K_{i} \Gamma_{i}}}{F_{i K_{i} K_{i}}} .
$$


Also, (2) should hold for any public capital level in the neighborhood. Replacing $i$ by $j$, $j \neq i$, in (2) and differentiating it with respect to $\Gamma_{i}$ produce

$$
\frac{\partial K_{j}}{\partial \Gamma_{i}}=\frac{\frac{\partial r}{\partial \Gamma_{i}}}{F_{j K_{j} K_{j}}} .
$$

It follows from (3) that $\frac{\partial K_{i}}{\partial \Gamma_{i}}+\sum_{j \neq i} \frac{\partial K_{j}}{\partial \Gamma_{i}}=0$. By summing up (A1) and (A2), we derive

$$
\frac{\partial r}{\partial \Gamma_{i}}=\frac{\frac{F_{i K_{i} \Gamma_{i}}}{F_{i K_{i} K_{i}}}}{\left(F_{i K_{i} K_{i}}\right)^{-1}+\sum_{j \neq i}\left(F_{j K_{j} K_{j}}\right)^{-1}}>0,
$$

since $F_{i K_{i} K_{i}}<0$ and $F_{i K_{i} \Gamma_{i}}>0$. Then, from (A2) and (A3), we derive

$$
\frac{\partial K_{j}}{\partial \Gamma_{i}}<0
$$

and subsequently from (3) and (A4), we have

$$
\frac{\partial K_{i}}{\partial \Gamma_{i}}>0
$$

\section{References}

[1] Abe, Hitoshi, Muneyuki Shindo and Sadafumi Kawato. 1990. Review of Contemporary Japanese Politics. University of Tokyo Press. (in Japanese)

[2] Anselin, Luc. 2001. Spatial econometrics. in: Baltagi, Badi H. ed., A Companion to Theoretical Econometrics. Blackwell.

[3] Anselin, Luc. 2007. Spatial econometrics in RSUE: Retrospect and prospect. Regional Science and Urban Economics 37: 450-456

[4] Austen-Smith, David, and John R. Wright. 1992. Competitive lobbying for a legislator's vote. Social Choice and Welfare 9, 229-257.

[5] Baicker, Katherine. 2005. The spillover effects of state spending. Journal of Public Economics 89, $529-544$ 
[6] Bernheim, B. Douglas, and Michael D. Whinston. 1986. Menu auctions, resource allocation, and economic influence. Quarterly Journal of Economics 101, 1-31.

[7] Besfamille, Martine. 2004. Collusion in local public works. International Economic Review 45(4): 1193-1219

[8] Borck, Rainald, Marco Caliendo and Viktor Steiner. 2007. Fiscal competition and the composition of public spending: Theory and evidence. FinanzArchiv 63(2), 264-277.

[9] Bosch, Núria and Albert Solé-Ollé. 2007. Yardstick competition and the political costs of raising taxes: An empirical analysis of Spanish municipalities. International Tax and Public Finance 14, $71-92$.

[10] Breuillé, Marie-Laure, Thierry Madiès, and Emmanuelle Taugourdeau. 2008. Soft budget constraint and equalization. mimeo.

[11] Brueckner, Jan K. 2003. Strategic interaction among governments: An overview of empirical studies. International Regional Science Review 26(2): 175-188

[12] Bucovetsky, S. 2005. Public input competition. Journal of Public Economics 89, 1763-1787.

[13] Bucovetsky, S., M. Marchand and P. Pestieau. 1998. Tax competition and revelation of preferences for public expenditure. Journal of Urban Economics 44, 367-390.

[14] Calabrese, Stephen, Dennis Epple, Thomas Romer, Holger Sieg. 2006. Local public good provision: voting, peer effects, and mobility. Journal of Public Economics 90: 959-981

[15] Case, Anne C., Harvey R. Rosen and James R. Hines Jr. 1993. Budget spillovers and fiscal policy interdependence: Evidence from the states. Journal of Public Economics 52, 285-307.

[16] Conley, T.G. 1999. GMM estimation with cross sectional dependence. Journal of Econometrics 92, $1-45$.

[17] Costa-Font, Joan, Jordi Pons-novell. 2007. Public health expenditure and spatial interactions in a decentralized national health system. Health Economics 16: 291-306.

[18] Dahlby, Bev. 1996. Fiscal externalities and the design of intergovernmental grants. International Tax and Public Finance 3, 397-412.

[19] Devereux, Michael P., Rachel Griffith, Helen Simpson. 2007. Firm location decisions, regional grants and agglomeration externalities. Journal of Public Economics 91: 413-435 
[20] Dixit, Avinash, Gene M. Grossman, and Elhanan Helpman. 1997. Common agency and coordination. Journal of Political Economy 105, 752-769.

[21] Doi, Taketo and Masahiro Ashiya. 1997. Disbursement of central government subsidies and the ruling parties. JCER Economic Journal 34, 180-195. (in Japanese)

[22] Esteban, Joan, and Debraj Ray. 2000. Wealth constraints, lobbying and the efficiency of public allocation. European Economic Review 44, 694-705.

[23] Esteban, Joan, and Debraj Ray. 2006. Inequality, lobbying, and resource allocation. American Economic Review 96, 257-279.

[24] Grossman, Gene M., and Elhanan Helpman. 1994. Protection for sale. American Economic Review 84, 833-850.

[25] Hayashi, Fumio. 2000. Econometrics. Princeton University Press.

[26] Jayet, Hubert and Sonia Paty. 2006. Capital indivisibility and tax competition: Are there too many business areas when some of them are empty? Journal of Urban Economics 60(3), 399-417.

[27] Keen, Michael and Maurice Marchand. 1997. Fiscal competition and the pattern of public spending. Journal of Public Economics 66, 33-53.

[28] Kelejian, Harry H. and Ingmar R. Prucha. 1998. A generalized spatial two-stage least squares procedure for estimating a spatial autoregressive model with autoregressive disturbances. Journal of Real Estate Finance and Economics 17(1), 99-121.

[29] Kelejian, Harry H. and Ingmar R. Prucha. 1999. A generalized moments estimator for the autoregressive parameter in a spatial model. International Economic Review 40(2), 509-533.

[30] Köthenbürger, Marko. 2004. Tax competition in a fiscal union with decentralized leadership. Journal of Urban Economics 55, 498-513.

[31] Köthenbürger, Marko. 2007. Implications for corrective policy. Journal of Public Economics 91, 481-496.

[32] Matsumoto, Mutsumi. 2000. A note on the composition of public expenditure under capital tax competition. International Tax and Public Finance 7(6), 691-697.

[33] Matsumoto, Mutsumi. 2004. The mix of public inputs under tax competition. Journal of Urban Economics 56(2), 389-396. 
[34] Moscone, Francesco, Martin Knapp, Elisa Tosetti. 2007. Mental health expenditure in England: A spatial panel approach. Journal of Health Economics 26: 842-864

[35] Nishio, Masaru. 1990. Administration and plan. in: Basic Concepts of Study of Public Administration. University of Tokyo Press. (in Japanese)

[36] Reed, Steven R. 1986. Japanese Prefectures and Policy Making. University of Pittsburgh Press.

[37] Revelli, Federico. 2005. On spatial public finance empirics. International Tax and Public Finance 12, 475-492.

[38] Revelli, Federico. 2006. Performance rating and yardstick competition in social service provision. Journal of Public Economics 90, 459-475.

[39] Potters, Jan, and Frans van Winden. 1992. Lobbying and asymmetric information. Public Choice 74, 269-292.

[40] Sato, Motohiro. 2007. The political economy of interregional grants. In: Boadway, Robin and Anwar Shah eds. Intergovernmental Fiscal Transfers: Principles and Practice. World Bank.

[41] Shimokobe, Atsushi. 1994. Depositions to National Development Plan. Nihon Keizai Hyoron Sha. (in Japanese)

[42] Sugahara, Kota and Minoru Kunisaki. 2006. Empirical analysis on fiscal competition: The case of Japanese prefectures. mimeo. (in Japanese)

[43] Sunahara, Yosuke. 2006. Political reasons for policy making in the Japanese local governments: Evidence from institutional perspective. Zaisei Kenkyu 2, 161-178. (in Japanese)

[44] Wildasin, David E. 1988. Nash equilibria in models of fiscal competition. Journal of Public Economics 35, 229-240.

[45] Zodrow, George R., and Peter Mieszkowski. 1986. Pigou, Tiebout, property taxation, and the underprovision of local public goods. Journal of Urban Economics 19, 356-370. 
Table 1. Descriptive statistics

\begin{tabular}{lrrrr}
\hline & mean & Std. dev. & \multicolumn{1}{c}{$\min$} & \multicolumn{1}{c}{$\max$} \\
\hline Size of industrial estates & 3.15 & 4.98 & 0.00 & 23.26 \\
Value of industrial estates & 22.74 & 63.35 & 0.00 & 357.92 \\
Director from the central & 0.19 & 0.40 & 0.00 & 1.00 \\
Workers on loan in the central & 12.91 & 10.33 & 1.00 & 63.00 \\
LDP members & 4.21 & 2.29 & 1.00 & 12.00 \\
Population density & 0.65 & 1.13 & 0.07 & 5.74 \\
Area size & 7.81 & 11.70 & 1.86 & 83.45 \\
Population size & 2.70 & 2.52 & 0.61 & 12.06 \\
Local tax revenue per capita & 2.47 & 0.51 & 1.54 & 4.73 \\
Local bond outstanding per capita & 6.32 & 1.86 & 2.76 & 11.43 \\
Existing establishment & 3.07 & 2.36 & 0.34 & 11.63 \\
\hline
\end{tabular}

(notes) Units: square kilometers (size of industrial estates); million yen (value of industrial estates); thousand person per square kilometers (population density); thousand square kilometers (area size); million (population size); hundred thousand Japanese yen (tax revenue and bond outstanding per capita); square kilometers (size of existing establishment); persons (workers on loan, directors, LDP members) 
Figure 1. Development of industrial estates: 2003-2006

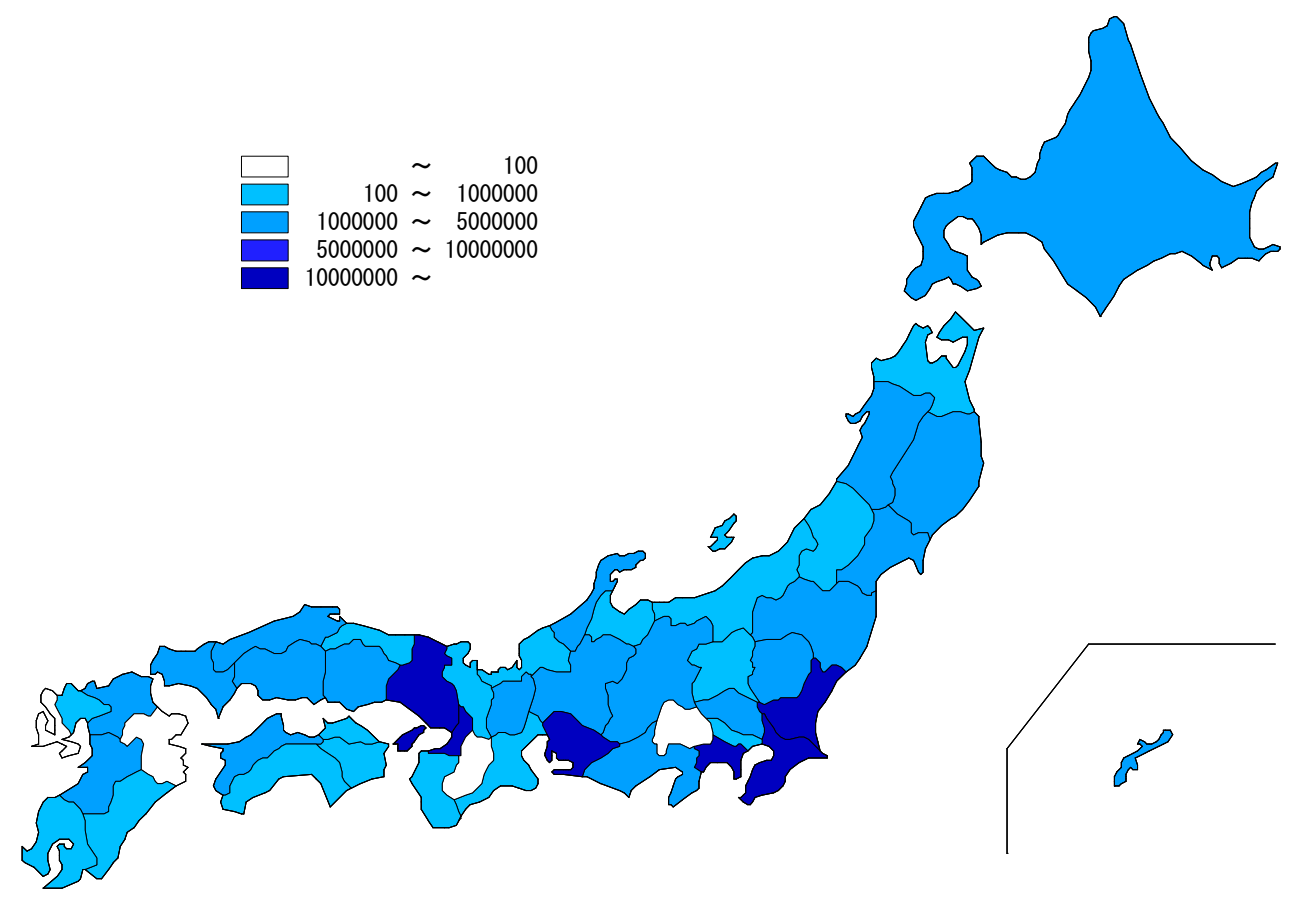

(notes) Unit: square meters. 
Table 2. Area of industrial estates: Simple GMM with triangular weights

\begin{tabular}{|c|c|c|c|c|c|}
\hline & Tax revenue & $\begin{array}{c}\text { Gross regional } \\
\text { expenditure }\end{array}$ & Contiguity & $\begin{array}{r}\text { Employme } \\
\text { income }\end{array}$ & \\
\hline \multirow[t]{2}{*}{ Spatial lag } & 0.388 & -0.145 & 0.347 & -0.191 & \\
\hline & $(0.26)$ & $(0.46)$ & $(0.44)$ & $(0.39)$ & \\
\hline \multirow[t]{2}{*}{ Director } & 0.927 & $1.213^{*}$ & 0.932 & 1.051 & * \\
\hline & $(0.66)$ & $(0.70)$ & $(0.67)$ & $(0.56)$ & \\
\hline \multirow[t]{2}{*}{ Workers on loan } & 0.069 & $0.070^{*}$ & 0.079 & 0.085 & ** \\
\hline & $(0.04)$ & $(0.04)$ & $(0.04)$ & $(0.04)$ & \\
\hline \multirow[t]{2}{*}{ LDP members } & -0.343 & -0.309 & -0.323 & -0.373 & ** \\
\hline & $(0.17)$ & $(0.21)$ & $(0.16)$ & $(0.17)$ & \\
\hline \multirow[t]{2}{*}{ Population density } & 0.074 & 0.135 & 0.101 & 0.023 & \\
\hline & $(0.16)$ & $(0.15)$ & $(0.15)$ & $(0.20)$ & \\
\hline \multirow[t]{2}{*}{ Tax revenue } & -0.245 & -0.383 & -0.200 & -0.194 & \\
\hline & $(0.33)$ & $(0.32)$ & $(0.41)$ & $(0.36)$ & \\
\hline \multirow[t]{2}{*}{ Bond outstanding } & -0.066 & -0.103 & -0.163 & -0.118 & \\
\hline & $(0.09)$ & $(0.09)$ & $(0.08)$ & $(0.09)$ & \\
\hline \multirow[t]{2}{*}{ Establishments } & 0.250 & $0.466^{*}$ & 0.436 & 0.381 & \\
\hline & $(0.24)$ & $(0.24)$ & $(0.20)$ & $(0.27)$ & \\
\hline \multirow[t]{2}{*}{ constant } & 1.319 & 2.096 & 1.425 & 1.902 & $*$ \\
\hline & $(0.86)$ & $(1.10)$ & $(1.12)$ & $(1.14)$ & \\
\hline 1st stage $F$ & 975.92 & 347.22 & 3.31 & 59.33 & \\
\hline Hansen's J & 17.71 & 19.06 & 13.31 & 14.57 & \\
\hline Centered R2 & 0.140 & 0.188 & 0.097 & 0.208 & \\
\hline \# of obs & 47 & 47 & 47 & 47 & \\
\hline
\end{tabular}

(note) Figures in parentheses are the standard errors. Spatial weights are based on triangular formula. 
Table 3. Value of industrial estates: Simple GMM with triangular weights

\begin{tabular}{|c|c|c|c|c|c|c|c|c|}
\hline \multirow[b]{2}{*}{ Spatial lag } & \multicolumn{2}{|c|}{ Tax revenue } & \multicolumn{2}{|c|}{$\begin{array}{c}\text { Gross regional } \\
\text { expenditure }\end{array}$} & \multicolumn{2}{|c|}{ Contiguity } & \multicolumn{2}{|c|}{$\begin{array}{c}\text { Employment } \\
\text { income }\end{array}$} \\
\hline & 0.434 & $* * *$ & 0.368 & $* * *$ & 0.023 & & 0.154 & \\
\hline & $(0.09)$ & & $(0.11)$ & & $(0.16)$ & & $(0.11)$ & \\
\hline \multirow[t]{2}{*}{ Director } & 1.390 & & 3.837 & & 1.664 & & 3.117 & \\
\hline & $(2.62)$ & & $(2.81)$ & & $(2.75)$ & & $(2.16)$ & \\
\hline \multirow[t]{2}{*}{ Workers on loan } & 0.339 & $* * *$ & 0.404 & *** & 0.343 & ** & 0.429 & *** \\
\hline & $(0.11)$ & & $(0.13)$ & & $(0.14)$ & & $(0.13)$ & \\
\hline \multirow[t]{2}{*}{ LDP members } & -1.133 & $* * *$ & -1.288 & $* *$ & -1.119 & $* *$ & -1.337 & $* * *$ \\
\hline & $(0.43)$ & & $(0.56)$ & & $(0.54)$ & & $(0.48)$ & \\
\hline \multirow[t]{2}{*}{ Population density } & 4.929 & $* * *$ & 5.889 & $* * *$ & 5.080 & $* * *$ & 5.793 & $* * *$ \\
\hline & $(0.81)$ & & $(0.69)$ & & $(1.01)$ & & $(1.13)$ & \\
\hline \multirow[t]{2}{*}{ Tax revenue } & -7.706 & $* * *$ & -4.401 & $* * *$ & -4.564 & $* * *$ & -3.427 & $* *$ \\
\hline & $(1.24)$ & & $(1.53)$ & & $(1.62)$ & & $(1.47)$ & \\
\hline \multirow[t]{2}{*}{ Bond outstanding } & -1.051 & $* * *$ & -1.177 & $* * *$ & -0.983 & $* * *$ & -0.828 & $* * *$ \\
\hline & $(0.25)$ & & $(0.31)$ & & $(0.33)$ & & $(0.30)$ & \\
\hline \multirow[t]{2}{*}{ Establishments } & 2.097 & $* * *$ & 1.730 & $*$ & 2.387 & ** & 1.992 & * \\
\hline & $(0.71)$ & & $(0.96)$ & & $(1.00)$ & & (1.06) & \\
\hline \multirow[t]{2}{*}{ constant } & 21.882 & $* * *$ & 14.905 & $* * *$ & 14.620 & $* * *$ & 10.872 & $* * *$ \\
\hline & (3.18) & & (4.07) & & $(3.35)$ & & $(3.91)$ & \\
\hline 1st stage $F$ & 6134.84 & & 1433.24 & & 5.31 & & 221.86 & \\
\hline Hansen's J & 12.91 & & 21.41 & $*$ & 10.48 & & 12.35 & \\
\hline Centered R2 & 0.503 & & 0.422 & & 0.413 & & 0.400 & \\
\hline \# of obs & 47 & & 47 & & 47 & & 47 & \\
\hline
\end{tabular}

(note) Figures in parentheses are the standard errors. Spatial weights are based on triangular formula. 
Table 4. Value of industrial estates: Simple GMM without zero-prefectures

\begin{tabular}{|c|c|c|c|c|c|c|c|c|}
\hline \multirow[b]{2}{*}{ Spatial lag } & \multicolumn{2}{|c|}{ Tax revenue } & \multicolumn{2}{|c|}{$\begin{array}{c}\text { Gross regional } \\
\text { expenditure }\end{array}$} & \multicolumn{2}{|c|}{ Contiguity } & \multicolumn{2}{|c|}{$\begin{array}{c}\text { Employment } \\
\text { income }\end{array}$} \\
\hline & 0.429 & $* * *$ & 0.365 & $* * *$ & -0.032 & & 0.134 & \\
\hline & $(0.05)$ & & $(0.11)$ & & $(0.21)$ & & $(0.12)$ & \\
\hline \multirow[t]{2}{*}{ Director } & 1.526 & & 4.985 & * & 3.054 & & 2.993 & $* *$ \\
\hline & (1.43) & & $(2.60)$ & & $(2.45)$ & & $(1.37)$ & \\
\hline \multirow[t]{2}{*}{ Workers on loan } & 0.324 & ${ }^{* * * *}$ & 0.347 & *** & 0.347 & *** & 0.379 & *** \\
\hline & $(0.10)$ & & $(0.12)$ & & $(0.12)$ & & $(0.11)$ & \\
\hline \multirow[t]{2}{*}{ LDP members } & -0.991 & ** & -1.251 & ** & -0.964 & * & -1.492 & *** \\
\hline & $(0.44)$ & & $(0.50)$ & & $(0.57)$ & & $(0.44)$ & \\
\hline \multirow[t]{2}{*}{ Population density } & 4.988 & $* * *$ & 5.827 & $* * *$ & 5.345 & *** & 6.132 & *** \\
\hline & $(0.46)$ & & $(0.30)$ & & $(1.10)$ & & $(0.80)$ & \\
\hline \multirow[t]{2}{*}{ Tax revenue } & -8.018 & $* * *$ & -5.125 & $* * *$ & -5.184 & *** & -4.766 & **** \\
\hline & $(1.06)$ & & $(1.27)$ & & $(1.71)$ & & $(1.30)$ & \\
\hline \multirow[t]{2}{*}{ Bond outstanding } & -1.034 & $* * *$ & -1.169 & $* * *$ & -1.001 & $* * *$ & -0.709 & $* * *$ \\
\hline & $(0.25)$ & & $(0.26)$ & & $(0.35)$ & & $(0.26)$ & \\
\hline \multirow[t]{2}{*}{ Establishments } & 2.071 & $* * *$ & 1.149 & & 2.492 & *** & 2.255 & $* *$ \\
\hline & $(0.64)$ & & $(0.80)$ & & $(0.89)$ & & $(0.92)$ & \\
\hline \multirow[t]{2}{*}{ constant } & 22.317 & $* * *$ & 17.786 & $* * *$ & 15.793 & $* * *$ & 13.451 & $* * *$ \\
\hline & $(2.57)$ & & $(3.27)$ & & (3.94) & & $(3.54)$ & \\
\hline 1st stage $F$ & 28857.29 & & 4456.24 & & 18.95 & & 235.95 & \\
\hline Hansen's J & 9.7659 & & 18.3038 & & 9.73485 & & 10.5139 & \\
\hline \# of obs & 43 & & 43 & & 43 & & 43 & \\
\hline
\end{tabular}

(note) Figures in parentheses are the standard errors. Spatial weights are based on triangular formula. 